Pesq. Vet. Bras. 28(4):216-222, abril 2008

\title{
Total intravenous anaesthesia with propofol-racemic ketamine and propofol-S-ketamine: A comparative study and haemodynamic evaluation in dogs undergoing ovariohysterectomy ${ }^{1}$
}

\author{
Tatiana R. Intelisano ${ }^{2 *}$, Flávia R. Kitahara², Denise A. Otsuki², Denise T. \\ Fantoni ${ }^{2}$, José O.C. Auler $\mathrm{Jr}^{3}$ and Sílvia R.G. Cortopassi ${ }^{2}$
}

\begin{abstract}
Intelisano T.R., Kitahara F.R., Otsuki D.A., Fantoni D.T., Auler Jr J.O.C. \& Cortopassi S.R.G. 2008. Total intravenous anaesthesia with propofol-racemic ketamine and propofol-S-ketamine: A comparative study and haemodynamic evaluation in dogs undergoing ovariohysterectomy. Pesquisa Veterinária Brasileira 28(4):216-222. Departamento de Cirurgia, Faculdade de Medicina Veterinária e Zootecnia, Universidade de São Paulo, Av. Prof. Dr. Orlando Marques Paiva 87, Cidade Universitária, São Paulo, SP 05508 000, Brazil. E-mail: intelizano@ yahoo.com.br

Total intravenous anaesthesia (TIVA) with propofol and ketamine proved to be very satisfactory from a clinical point of view. This blind randomised controlled trial was designed to compare induction and maintenance of anaesthesia under continuous infusion of propofol-racemic ketamine (PRK) with that of propofol-S-ketamine (PSK) and evaluate their haemodynamic, metabolic and ventilatory effects. Seven female dogs undergoing ovariohysterectomy were involved in each group. Anaesthesia was induced: in Group PRK, with propofol $\left(4.0 \mathrm{mg} \mathrm{kg}^{-1}\right)$ and racemic ketamine $\left(2.0 \mathrm{mg} \mathrm{kg}^{-1}\right)$ intravenous (i.v.), followed by i.v. infusion of propofol (initial dose of $0.5 \mathrm{mg} \mathrm{kg}^{-1} \mathrm{~min}^{-1}$ ) and racemic ketamine $\left(0.2 \mathrm{mg} \mathrm{kg}^{-1} \mathrm{~min}^{-1}\right)$; in Group PSK, with propofol $\left(4.0 \mathrm{mg} \mathrm{kg}^{-1}\right)$ and S-ketamine $\left(1.0 \mathrm{mg} \mathrm{kg}^{1}\right)$ i.v., followed by i.v. infusion of propofol (initial dose of $0.5 \mathrm{mg} \mathrm{kg}^{-1} \mathrm{~min}^{-1}$ ) and S-ketamine $\left(0.1 \mathrm{mg} \mathrm{kg}^{-1} \mathrm{~min}^{-1}\right)$. Parameters were assessed before anaesthesia and in 6 time points after induction. In both groups, heart rate increased significantly at all time points. There was a slight decrease in systemic blood pressure, cardiac output and cardiac index in both groups. The systolic index decrease significantly and intense respiratory depression was observed in all groups, making assisted ventilation necessary.
\end{abstract}

INDEX TERMS: Anaesthesia, haemodynamic, propofol, ketamine, dog.

RESUMO.- [Anestesia total intravenosa com propofolquetamina racêmica e propofol quetamina-S: estudo comparativo e avaliação hemodinâmica em cães submetidos à ovariohisterectomia.] A anestesia total intravenosa (TIVA) com propofol e quetamina proporciona um

\footnotetext{
${ }^{1}$ Received on August 8, 2007.

Accepted for publication on April 18, 2008.

${ }^{2}$ Departamento de Cirurgia, Faculdade de Medicina Veterinária e Zootecnia, Universidade de São Paulo (USP), Av. Prof. Dr. Orlando Marques Paiva 87, Cidade Universitária, São Paulo, SP 05508-000, Brazil. *Corresponding author: intelizano@yahoo.com.br

${ }^{3}$ Disciplina de Anestesiologia, Departamento de Cirurgia, Faculdade de Medicina, USP, Av. Dr. Enéas de Carvalho Aguiar 44, $2^{\circ}$ andar, Bloco I, Cerqueira César, São Paulo, SP 05403-900.
}

efeito muito satisfatório do ponto de vista clínico. Este estudo, cego e randomizado, comparou a indução e manutenção da anestesia com infusão contínua de propofolquetamina racêmica (PRK) e propofol-quetamina-S (PSK) em cães, e avaliou seus efeitos hemodinâmicos, metabólicos e ventilatórios. Foram avaliadas sete cadelas em cada grupo, submetidas à ovariohisterectomia. A anestesia foi induzida no Grupo PRK, com propofol $\left(4.0 \mathrm{mg} \mathrm{kg}^{-1}\right) \mathrm{e}$ cetamina $\left(2.0 \mathrm{mg} \mathrm{kg}^{-1}\right)$ por via intravenosa (i.v.), seguida de infusão contínua de propofol (dose inicial de $0.5 \mathrm{mg} \mathrm{kg}^{-}$ $\left.{ }^{1} \mathrm{~min}^{-1}\right)$ e cetamina racêmica $\left(0.2 \mathrm{mg} \mathrm{kg}^{-1} \mathrm{~min}^{-1}\right)$ i.v. No Grupo PSK, a indução anestésica foi com propofol $\left(4.0 \mathrm{mg} \mathrm{kg}^{-}\right.$ $\left.{ }^{1}\right)$ e cetamina-S $\left(1.0 \mathrm{mg} \mathrm{kg}^{-1}\right)$ i.v., seguida de infusão contínua de propofol (dose inicial de $0,5 \mathrm{mg} \mathrm{kg}^{-1} \mathrm{~min}^{-1}$ ) e 
cetamina-S $\left(0.1 \mathrm{mg} \mathrm{kg}^{-1} \mathrm{~min}^{-1}\right)$ i.v. Os parâmetros foram observados antes da anestesia e em seis momentos após a indução anestésica.

Em ambos os grupos, a freqüência cardíaca elevouse significantemente em todos os momentos. Houve pequena redução na pressão arterial sistêmica, débito cardíaco e índice cardíaco. O índice sistólico apresentou redução significante e houve intensa depressão respiratória em ambos os grupos. A anestesia total intravenosa com a associação do propofol à cetamina racêmica ou à cetamina-S proporciona boa estabilidade hemodinâmica, entretanto, há intensa depressão respiratória, havendo necessidade de assistência ventilatória.

TERMOS DE INDEXAÇÃO: Anestesia, hemodinâmica, propofol, cetamina, cão.

\section{INTRODUCTION}

Propofol produces its anaesthetic effect by acting at GABA receptors (Stoelting 1999). Propofol pharmacokinetic properties contribute to its rapid clearance from the body (Nolan \& Reid 1993). The anaesthetic and side effects of propofol are largely dose-related, and it would be therefore advantageous to combine propofol with other anaesthetic agents in order to decrease the dose, and minimize these adverse effects.

The hypnotic and anaesthetic actions of ketamine are thought to be via N-methyl-D-aspartate (NMDA) receptors (Mayer \& Miller 1990). NMDA antagonism results in blockage of spinal nociceptive reflexes (Hara et al. 1993), by blocking the conduction of painful impulses to the thalamus and to areas of the cortex (White et al. 1982). Furthermore, there is an interaction with the opioid receptors $\mu$ and sigma (James et al. 1984; Parsons et al. 1998), the muscarinic receptors and the calcium channels (Hirota \& Lambert 1996).

Blockage of NMDA receptors with low doses of ketamine is desirable for a good analgesic effect (Ryder et al. 1978). This analgesic effect is due to reduction of nociceptives reflections of the spinal medulla (Kitahata et al. 1973) that are otherwise activated in response to pain.

Hemelrijck \& White (1997) studies have shown that $\mathrm{S}(+)$-ketamine is potent in binding to $\mathrm{N}$-methyl-D-aspartate (NMDA) opioid receptors and efficient in blocking NMDA and acetylcholine induced neuronal currents.

In man, $\mathrm{S}(+)$ Ketamine has an anaesthetic-analgesic effect two to four times greater than racemic ketamine (White et al. 1985; Mathisen et al. 1995; Lauretti et al. 2000 ), and its hyptonic effect is more potent than that of the $\mathrm{R}(-)$ isomer (Terra et al. 1999), allowing the use of lower doses of $\mathrm{S}(+)$ ketamine compared to racemic ketamine.

In man, total intravenous anaesthesia (TIVA) with propofol and ketamine proved to be very satisfactory from a clinical point of view (Schüttler et al. 1991). This combination allows a reduction in the hypnotic dose of propofol and a decrease in the cardiovascular depression induced by this drug (Badrinath et al. 2000). According to Schüttler et al. (1991) the major side effects of propofol (reduced haemodynamics during induction) and ketamine (psychic disturbances and cardiovascular stimulation) were absent and respiratory function post-surgery was adequate. However, a study by Loh \& Dalen (2007) using the ketamine-propofol combination in humans, showed that some patients experienced significant hemodynamic and respiratory compromise, highlighting the need for further research on the use of this drug combination for routine sedation and analgesia.

To this end, we wish to compare the induction and maintenance of anaesthesia under continuous infusion of propofol-racemic ketamine with that of propofol-S-ketamine in female dogs undergoing ovariohysterectomy and evaluate their haemodynamic, metabolic and ventilatory effects.

\section{MATERIALS AND METHODS}

The study was approved by the Ethics Committee for the Analysis of Research Projects of the Hospital das Clínicas and of the School of Medicine, University of São Paulo. A comparative double-blind randomized study design was evaluated. Seven healthy female mongrel dogs, aged 1 to 5 years, weighing 13.7 $\pm 1.9 \mathrm{~kg}$ were evaluated in each group in this investigation. Health status was based on physical examination, complete blood count, biochemical profile and blood gases.

Food was withheld from all animals for 12 and water for 4 hours prior to the beginning of the study. No premedication was used. To allow an adequate instrumentation, anaesthesia was induced with isoflurane (Forane, Abbott, São Paulo, Brazil) delivered by face-mask and carried in $50 \%$ oxygen at a flow rate of $1 \mathrm{~L}$ minute ${ }^{-1}$. When jaw relaxation was adequate the trachea was intubated (Magill, Rusch, Kernen, Germany). The endotracheal tube was connected to a rebreathing circuit (Cicero, Dräguer, Lübeck, Germany). Dogs were placed in dorsal recumbence and maintained at one MAC of isoflurane (1.4\%). An anaesthetic agent analyser (Anaesthetic Gas Analyser and Capnograph, Criticare Systems INC, Wisconsin, USA) was used to determine isoflurane end expiratory concentration and end-tidal $\mathrm{CO}_{2}$ concentration. Oxygen saturation, rectal temperature and the eletrocardiogram were measured continuously (Viridia, Model 66S, Hewlett Packard, Boeblingen, Germany). The cephalic veins were canulated with a polyethylene 20 SWG catheter (Insyte, Becton Dickenson, Juiz de Fora, Brazil) and, during the entire procedure, lactated Ringer's solution was administered at an infusion rate of $10 \mathrm{ml} \mathrm{kg}^{-1}$ hour $^{-1}$ (Ringer Lactate Solution, Baxter, São Paulo, Brazil).

The femoral vein and artery were dissecated to allow introduction of the pulmonary artery catheter (Swan Ganz Thermodilution Catheter Model 744H-7.5F, Baxter Healthcare Corporation, CA, USA) and of an arterial cannula for systemic arterial pressure monitoring respectively. Local anaesthesia with $2 \%$ lignocaine $\left(7.0 \mathrm{mg} \mathrm{kg}^{-1}\right.$ ) (Xylestesin; Cristália, São Paulo, Brazil) was performed to provide adequate analgesia.

The dogs were placed in right lateral recumbency for recovery of the inhalatory anaesthesia. Sixty minutes after the suspension of inhalatory anaesthesia, baseline haemodynamics parameters were collected (heart rate; systolic, diastolic and 
mean arterial pressure; mean pulmonary arterial pressure; wedge pressure, central venous pressure and cardiac output). Other variables such as cardiac index, stroke index, systemic vascular resistance index and pulmonary vascular resistance index were calculated by the computer. Arterial blood and mixed venous samples were collected from femoral artery and from pulmonary artery catheter for $\mathrm{pH}$, blood gases, bicarbonate, oxygen saturation, electrolytes and lactate evaluation in a blood gas analyzer (ABL blood gas analyzer; Radiometer, Copenhagen, Denmark).

The bitchs were then randomly divided into two groups:

- Group propofol-racemic ketamine (PRK): induction of anaesthesia was performed with propofol $\left(4.0 \mathrm{mg} \mathrm{kg}^{-1}\right)$ plus racemic ketamine $\left(2.0 \mathrm{mg} \mathrm{kg}^{-1}\right)$ also administered i.v. slowly in a single bolus, immediately followed by i.v. infusion of propofol (initial dose of $0.5 \mathrm{mg}$ $\left.\mathrm{kg}^{-1} \mathrm{~min}^{-1}\right)$ and racemic ketamine $\left(0.2 \mathrm{mg} \mathrm{kg}^{-1} \mathrm{~min}^{-1}\right)$;

- Group propofol-S(+)ketamine (PSK): induction of anaesthesia was performed with propofol $\left(4.0 \mathrm{mg} \mathrm{kg}^{-1}\right)$ and S-ketamine $(1.0 \mathrm{mg} \mathrm{kg}$ $\left.{ }^{1}\right)$ administered i.v. and maintained by continuous infusion of propofol (initial dose of $0,5 \mathrm{mg} \mathrm{kg}^{-1} \mathrm{~min}^{-1}$ ) and S-ketamine $\left(0.1 \mathrm{mg} \mathrm{kg}^{-1} \mathrm{~min}^{-1}\right)$.

After the animals became recumbent, the trachea was intubated. Separate infusion pumps (Infusion Pump-670, Santronic, São Paulo, Brazil) were used for different drugs and the dogs anaesthetized for ovariohysterectomy, performed always by the same surgeon.

In both groups, the maintenance doses of propofol were given based on its effect. The doses were elevated or reduced under alterations of heart rate and systolic blood pressure. Whenever heart rate and systolic blood pressure increased by $20 \%$, a bolus injection of $20 \%$ of induction dose of propofol was given and infusion rates were increased by $20 \%$ over the previous value, waiting 3 minutes before resuming surgery.

The quality of induction was evaluated using clinical criteria and expressed as good (good muscle relaxation, easy intubation and no jaw tone), intermediate (poor muscle relaxation, difficult intubation) or poor (excitability and impossible intubation). Induction time was defined as the period beginning with anaesthetics administration and ending when the trachea was intubated. Orotracheal intubation and the anaesthetic evaluation were performed by the same observer. The animals were initially maintained on spontaneous ventilation, with assisted ventilation introduced when $\mathrm{ETCO}_{2}$ values reached $45 \mathrm{mmHg}$. A respiratory rate of 10-15 breaths minute ${ }^{-1}$, a tidal volume of $10 \mathrm{ml} \mathrm{kg}^{-1}$ with a peak inspiratory pressure of $15 \mathrm{~cm} \mathrm{H} \mathrm{H}_{2} \mathrm{O}$ and $\mathrm{FiO}_{2}$ of 0.5 were used after induction.

The parameters were assessed immediately before induction of anaesthesia (baseline or M1), five minutes after (M2), at the time of skin incision (M3), at the time of the ovarian pedicle clamping (M4), at the time of suture of the abdominal wall (M5) and thirty minutes after the end of infusion (M6).

Recovery times (tracheal extubation, head lift and sternal recumbency unaided) were measured from the time the infusion was switched off.

Results were expressed as mean values $( \pm S D)$. A one-way ANOVA with repeated measures, followed by the Tukey's test was used to analyze changes in the physiologic and calculated parameters between different observation times (GraphPad InStat, version 3.01, San Diego, CA, USA). For between-group comparisons, Unpaired's t-test was used. The level of significance established was $5 \%(p<0.05)$.

\section{RESULTS}

Induction of anaesthesia was good in all animals. In groups PRK and PSK the maintenance mean doses of propofol were slightly increased in relation to the initial doses, $14 \%$ and $28.5 \%$, respectively (Table 1 ). Time of drug infusion was 65.5 ( \pm 11.4$)$ minutes for group PRK and 67.8 ( \pm 14.0$)$ minutes for group PSK.

Table 1. The mean values and standard deviations ( \pm SD) for doses of propofol ( $\mathrm{mg} \mathrm{kg}^{-1} \mathrm{~min}^{-1}$ ) combined with 0.2 $\mathrm{mg} \mathrm{kg}^{-1} \mathrm{~min}^{-}$of racemic ketamine (PRK, $\mathrm{n}=7$ ) and combined with $0.1 \mathrm{mg} \mathrm{kg}^{-1} \mathrm{~min}^{-} \mathrm{S}-\mathrm{ketamine}$ (PSK, $\mathrm{n}=7$ ) at the different assessment time points

\begin{tabular}{cccccc}
\hline \multicolumn{3}{c}{$\begin{array}{c}\text { Groups At } 5 \text { minutes Skin incision } \\
\text { of infusion }\end{array}$} & $\begin{array}{c}\text { Pedicle } \\
\text { clamping }\end{array}$ & $\begin{array}{c}\text { Suture of } \\
\text { abdominal } \\
\text { wall }\end{array}$ \\
\hline $\begin{array}{c}\text { Propofol } \\
\left(\mathrm{mg} \mathrm{kg}^{-1}\right. \\
\left.\mathrm{min}^{-1}\right)\end{array}$ & PSK & $0.5 \pm 0$ & $0.40 \pm 0.12$ & $0.43 \pm 0.11$ & $0.37 \pm 0.10$ \\
& & $0.5 \pm 0$ & $0.41 \pm 0.16$ & $0.49 \pm 0.21$ & $0.41 \pm 0.16$ \\
& & & &
\end{tabular}

During maintenance of anesthesia, heart rate increased significantly in both groups and in all anaesthetic time points in relation to the baseline (M1). In group PRK the increase was equivalent to $68 \%$ and in group PSK, $54 \%$ at five minutes after induction (M2); at the time of skin incision (M3) the increase was 68\% in Group PRK, and 58\% in Group PSK; at the time of the ovarian pedicle clamping (M4) the increase was 50\% in Group PRK and PSK in relation to M1 (Table 2, Fig.1) in relation to M1. The Group PSK showed significant increased values then Group PRK at thirty minutes after the end of infusion (M6) (Table 2).

In both groups, systolic arterial blood pressure (SAP) showed stable values close to those of baseline. Diastolic arterial blood pressure (DAP) values in Group PRK were

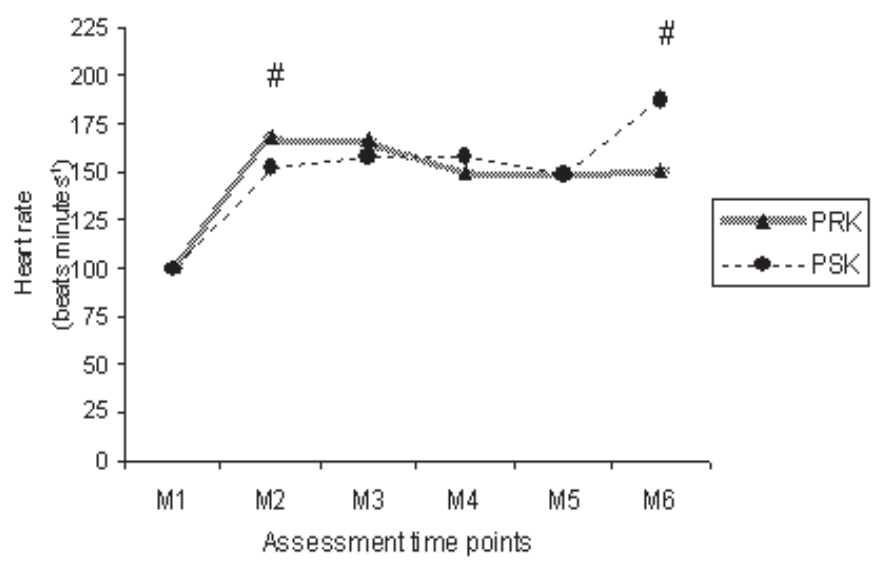

Fig.1. Changes in cardiac rate of animals included in the two experimental protocols at different assessment time points; \# PSK differs significantly from PRK $(p<0.05)$. M1 or baseline, immediately before the induction of anaesthesia; M2, at 5 minutes of infusion; M3, at the time of skin incision; M4, at the time of the ovarian pedicle clamping; M5, at the time of suture of the abdominal wall; M6, 30 minutes after the end of infusion. 
Table 2. The mean values ( $\pm S D$ ) for direct and calculated haemodynamic parameters of the dogs treated with propofol-racemic ketamine (PRK) and propofol-S-ketamine (PSK) at the different assessment time points

\begin{tabular}{|c|c|c|c|c|c|c|c|}
\hline Parameters & Groups & Baseline & $\begin{array}{l}\text { At } 5 \text { minutes } \\
\text { of infusion }\end{array}$ & Skin incision & $\begin{array}{l}\text { Pedicle } \\
\text { clamping }\end{array}$ & $\begin{array}{c}\text { Suture of } \\
\text { abdominal wall }\end{array}$ & $\begin{array}{l}\text { At } 30 \text { minutes } \\
\text { of recovery }\end{array}$ \\
\hline $\mathrm{HR}$ & PRK & $100 \pm 14.2$ & $168^{*}{ }^{*} \pm 23.2$ & $167^{*} \pm 26.2$ & $150^{*} \pm 25.0$ & $149^{*} \pm 23.0$ & $151^{*} \pm 28.6$ \\
\hline (beats $\min ^{-1}$ ) & PSK & $99 \pm 14.4$ & $152^{*} \pm 29.0$ & $158^{\star} \pm 28.4$ & $158^{*} \pm 25.6$ & $149^{*} \pm 24.1$ & $187^{\star \#} \pm 24.6$ \\
\hline SAP & PRK & $154 \pm 27.7$ & $142 \pm 27.0$ & $139 \pm 30.4$ & $150 \pm 35,5$ & $131 \pm 22.7$ & $185^{*} \pm 25.3$ \\
\hline$(\mathrm{mm} \mathrm{Hg})$ & PSK & $164 \pm 21.6$ & $138 \pm 16.9$ & $141 \pm 16.3$ & $167 \pm 13.4$ & $136 \pm 27.9$ & $150 \pm 32.8$ \\
\hline DAP & PRK & $93 \pm 14.8$ & $93 \pm 20.1$ & $95 \pm 19.0$ & $110 \pm 24.4$ & $95 \pm 16.2$ & $108 \pm 22.2$ \\
\hline$(\mathrm{mm} \mathrm{Hg})$ & PSK & $96 \pm 15.4$ & $95 \pm 18.6$ & $96 \pm 19.9$ & $119 \pm 16.7$ & $96 \pm 19.4$ & $127 \pm 15.2$ \\
\hline MAP & PRK & $116 \pm 19.2$ & $111 \pm 21.1$ & $111 \pm 21.6$ & $121 \pm 24.0$ & $109 \pm 9.6$ & $123 \pm 24.6$ \\
\hline$(\mathrm{mm} \mathrm{Hg})$ & PSK & $121 \pm 6.2$ & $111 \pm 17.5$ & $111 \pm 15.9$ & $135 \pm 15.1$ & $108 \pm 18.9$ & $145 \pm 16.9$ \\
\hline PAP (M) & PRK & $15.7 \pm 2.1$ & $15.2 \pm 1.8$ & $15.7 \pm 2.9$ & $16.4 \pm 3.9$ & $15.4 \pm 2.5$ & $13.7 \pm 3.5$ \\
\hline (mm Hg) & PSK & $14.4 \pm 3.4$ & $14.5 \pm 2.3$ & $15.1 \pm 2.8$ & $15.8 \pm 3.0$ & $14.1 \pm 1.7$ & $15.1 \pm 2.1$ \\
\hline PAOP & PRK & $6.7 \pm 2.0$ & $6.7 \pm 1.8$ & $8.7 \pm 2.0$ & $8.1 \pm 2.3$ & $8.2 \pm 1.7$ & $6.0 \pm 1.9$ \\
\hline$(\mathrm{mm} \mathrm{Hg})$ & PSK & $5.4 \pm 0.9$ & $6.5 \pm 1.2$ & $7.1 \pm 2.9$ & $8.5 \pm 2.1$ & $7.4 \pm 1.62$ & $5.8 \pm 2.4$ \\
\hline CVP & PRK & $4.7 \pm 0.9$ & $5.5 \pm 0.9$ & $7.2 \pm 1.9$ & $8.4 \pm 1.2$ & $6.8 \pm 1.7$ & $6.1 \pm 2.0$ \\
\hline$(\mathrm{mm} \mathrm{Hg})$ & PSK & $4.7 \pm 2.2$ & $5.0 \pm 1.6$ & $5.5 \pm 3.2$ & $6.2 \pm 3.4$ & $4.5 \pm 2.7$ & $5.1^{*} \pm 3.0$ \\
\hline $\mathrm{Cl}$ & PRK & $4.57 \pm 0.78$ & $3.80 \pm 0.55$ & $3.91 \pm 0.89$ & $3.38 \pm 1.00$ & $3.36 \pm .10$ & $4.18 \pm 1.41$ \\
\hline$\left(\mathrm{L} \mathrm{min}^{-1} \mathrm{~m}^{-2}\right)$ & PSK & $3.98 \pm 0.83$ & $3.47 \pm 0.95$ & $3.81 \pm 0.97$ & $4.02 \pm 0.75$ & $3.23 \pm 0.86$ & $5.25 \pm 1.34$ \\
\hline $\mathrm{SI}$ & PRK & $45.6 \pm 2.8$ & $22.8^{\star} \pm 3.8$ & $23.9^{\star} \pm 6.9$ & $23.4^{\star} \pm 9.7$ & $23.1^{*} \pm 8.8$ & $27.2 \pm 7.4$ \\
\hline$\left(\mathrm{ml} \mathrm{m}^{-2}\right.$ batt $\left.^{-2}\right)$ & PSK & $40.5 \pm 8.59$ & $23.5^{\star} \pm 7.6$ & $24.9^{\star} \pm 8.0$ & $26.3^{*} \pm 7.8$ & $22.0^{*} \pm 7.0$ & $28.2^{*} \pm 7.3$ \\
\hline SVRI & PRK & $1933 \pm 365$ & $2209 \pm 518$ & $2181 \pm 573$ & $2544 \pm 341$ & $2599 \pm 726$ & $2422 \pm 748$ \\
\hline (dina seg $\mathrm{cm}^{-5} \mathrm{~m}^{-2}$ ) & PSK & $2299 \pm 311$ & $2278 \pm 477$ & $2208 \pm 622$ & $2519 \pm 383$ & $2608 \pm 413$ & $2269 \pm 608$ \\
\hline PVRI & PRK & $147 \pm 30$ & $159 \pm 17$ & $137 \pm 61$ & $163 \pm 64$ & $177 \pm 45$ & $136 \pm 43$ \\
\hline (dina seg $\mathrm{cm}^{-5} \mathrm{~m}^{-2}$ ) & PSK & $139 \pm 78$ & $162 \pm 42$ & $160 \pm 41$ & $128 \pm 37$ & $167 \pm 61$ & $155 \pm 34$ \\
\hline
\end{tabular}

${ }^{*} p<0.05$, significant difference in relation to baseline value; $\# p<0.05$, significant difference in relation to the other group; HR, Heart rate; SAP = systolic arterial blood pressure; DAP = diastolic arterial blood pressure; MAP = mean arterial blood pressure; $\mathrm{PAP}=$ pulmonary artery pressure; $\mathrm{PAOP}=$ pulmonary artery occlusion pressure; $\mathrm{CVP}=$ central venous pressure; $\mathrm{Cl}=$ cardiac index; $\mathrm{SI}=$ systolic index; SVRI = systemic vascular resistance index; PVRI = pulmonary vascular resistance index.

stable and close to the baseline. In group PSK, DAP values increased slightly after thirty minutes of the end of infusion (M6) (Table 2). In both groups, mean arterial blood pressure (MAP) values were stable, close to baseline, with a slight increase at the time of ovarian pedicle clamping (M4) and thirty minutes after the end of infusion (M6) (Table 2). The Group PSK showed slight increased values then Group PRK, in M6.

Cardiac index $(\mathrm{Cl})$ alterations were not observed in both groups. A significant reduction in systolic index (SI) occurred in the two studied groups. In group PRK, a 50\% reduction occurred in $\mathrm{M} 2$ and was maintained until M5. In PSK the reduction was $41 \%$ in M2 reaching up to $45 \%$ in M5 (Table 2).
Both groups showed increase in systemic vascular resistance index (SVRI) especially at the time of ovarian pedicle clamping (M4) (Table 1).

There was intense respiratory depression following induction at the beginning of infusion of the drugs in the both groups, with animals returning to spontaneous ventilation only after all anaesthetics infusions were stopped. A slight increase in carbon dioxide pressure on the arterial blood due to respiratory depression was observed, leading to respiratory acidosis with significant reduction of arterial blood $\mathrm{pH}$ values (Table 3).

PSK animals showed faster recovery, with earlier extubation time, quicker head-up and shorten sternal recumbency duration (Table 4). At that time, all animals

Table 3. Mean values $( \pm S D)$ of the arterial blood gases of the dogs treated with propofol-racemic ketamine (PRK) and propofol-S-ketamine (PSK) at the different assessment time points

\begin{tabular}{|c|c|c|c|c|c|c|c|}
\hline Parameters & Groups & Baseline & $\begin{array}{l}\text { At } 5 \text { minutes } \\
\text { of infusion }\end{array}$ & Skin incision & $\begin{array}{l}\text { Pedicle } \\
\text { clamping }\end{array}$ & $\begin{array}{c}\text { Suture of } \\
\text { abdominal wall }\end{array}$ & $\begin{array}{l}\text { At } 30 \text { minutes } \\
\text { of recovery }\end{array}$ \\
\hline Resp & PRK & 20.1 & $11.7 \pm 7.1$ & 14.00 & $9.71 \pm 3.9$ & $13.86 \pm 3.5$ & $28.57 \pm 16.4$ \\
\hline (breaths & PSK & 22.8 & $11.9 \pm 3.5$ & 11 & $13.43=$ & 13 & 4.6 \\
\hline $\mathrm{PaO}_{2}$ & PRK & $98.8 \pm 8.2$ & $402.2 \pm 44.9$ & $426.2 \pm 17.7$ & $446.0 \pm 16.1$ & $435.8 \pm 20.9$ & $89.7 \pm 8.7$ \\
\hline (mm Hg) & PSK & $96.1 \pm 9.8$ & $407.5 \pm 37.0$ & $426.2 \pm 48.9$ & $405.5 \pm 89.1$ & $411.5 \pm 65.4$ & $87.7 \pm 10.4$ \\
\hline $\mathrm{PaCO}_{2}$ & PRK & $32.7 \pm 1.8$ & $48.8^{\star} \pm 6.4$ & $47.1^{*} \pm 8.9$ & $48.0^{*} \pm 7.3$ & $48.4^{\star} \pm 5.2$ & $43.2 \pm 10.7$ \\
\hline (mm Hg) & PSK & $31.7 \pm 2.1$ & $47.5^{\star} \pm 3.7$ & $53.4^{*} \pm 7.7$ & $53.1^{*} \pm 7.6$ & $48.2^{*} \pm 4.1$ & $41.5^{\star} \pm 5.1$ \\
\hline \multirow[t]{2}{*}{$\mathrm{pH}$} & PRK & $7.38 \pm 0.04$ & $7.25^{*} \pm 0.03$ & $7.27^{\star} \pm 0.06$ & $7.24^{*} \pm 0.04$ & $7.25^{\star} \pm 0.04$ & $7.32 \pm 0.04$ \\
\hline & PSK & $7.39 \pm 0.02$ & $7.29^{\star} \pm 0.05$ & $7.26^{*} \pm 0.05$ & $7.25^{*} \pm 0.04$ & $7.28^{*} \pm 0.05$ & $7.35 \pm 0.05$ \\
\hline
\end{tabular}

${ }^{*} \mathrm{p}<0.05$, significant difference in relation to baseline value. 
Table 4. Mean values and standard deviations of the recovery times measured from the end of the infusion of propofolracemic ketamine (PRK) and propofol-S-ketamine (PSK)

\begin{tabular}{lcccc}
\hline & Groups & $\begin{array}{c}\text { Tracheal } \\
\text { extubation } \\
\text { (minutes) }\end{array}$ & $\begin{array}{c}\text { Head Lift } \\
\text { (minutes) }\end{array}$ & $\begin{array}{c}\text { Sternal } \\
\text { tecumbency } \\
\text { (minutes) }\end{array}$ \\
\hline Propofol $\left(\mathrm{mg} \mathrm{kg}^{-1} \mathrm{~min}^{-1}\right.$ ) & PRK & $17.0 \pm 9.3$ & $36.4 \pm 15.4$ & $39.1 \pm 10.8$ \\
& PSK & $10.7 \pm 8.9$ & $31.2 \pm 14.3$ & $35.1 \pm 6.2$
\end{tabular}

received $2 \mathrm{mg} / \mathrm{kg}$ of tramadol cloridrate i.m. for adequate post surgery analgesia.

\section{DISCUSSION}

The aim of this study was to evaluate and compare the induction and maintenance of anaesthesia under TIVA of propofol and $\mathrm{S}(+)$ ketamine with that of propofol and racemic ketamine. We asked if the benefits of $S(+)$ ketamine reported for other species (Ryder et al. 1978, White et al. 1985, Pfenninger et al. 2002, Strümper et al. 2004) regarding its clinically apparent potency, overall quality of anesthesia and decreased undesirable effects, would have a synergistic effect when associated to propofol.

Premedications as well as different degrees of surgical stimulus and the concurrent use of other drugs may complicate comparison of different anaesthetic drugs both at combined administration.

The combination of ketamine and propofol has been used in anaesthesia induction in dogs (Lerche et al. 2000) and in man, with good clinical and anaesthetic results (Mayer et al. 1990, Guit et al. 1991, Palermo et al. 1991, Schüttler et al. 1991, Hérnandez et al. 1999). This combination showed a positive synergistic effect when compared to both drugs alone. Propofol with racemic ketamine or Sketamine in TIVA allowed a reduction of 50 to $60 \%$ in the doses when compared to single administration (Hui et al.1995, Watkins et al. 1987, Mannarino 2002).

In man, $\mathrm{S}(+)$ Ketamine has an anaesthetic-analgesic effect two to four times greater than racemic ketamine (White et al. 1985, Mathisen et al. 1995, Lauretti et al. 2000), and its hyptonic effect is more potent than that of the R(-) isomer (Terra et al. 1999), witch allows the use of lower doses of $\mathrm{S}(+)$ ketamine when compared to racemic ketamine. Rossetti et al. (2008) observed in stallions undergoing castration, a higher analgesic effect of $\mathrm{S}(+)$ ketamine, which was represented by a more stable physiologic parameters during the procedure and also a lower anesthetic requirement.

Our results show that propofol combined with both ketamines for TIVA promotes good surgical conditions with no evisceration and good relaxation. Nevertheless the PSK group required an extra dose of propofol when compared to the PRK group during surgical procedure, indicating lower dose efficiency of the drugs.

Induction and maintenance of anaesthesia with propofol during various surgical procedures in man led to reduction in heart rate and arterial blood pressure (Scarrone et al.
1990, Hui et al. 1995). Propofol decreases arterial blood pressure by decreasing peripheral vascular resistance and myocardial contractility (Gauss et al. 1991, Pagel \& Warltier 1993). According to some authors, propofol promotes decrease in cardiac output (Maneglia \& Cousin 1988, Goodchild \& Serrao 1989) and increase in heart rate to compensate the decrease in arterial blood pressure (Hall \& Chambers 1987, Claeys et al. 1988). On the other hand, anaesthesia with ketamine produces an excessive sympathomimetic action with increases the heart rate and arterial blood pressure (White et al. 1980), as well as a dose-related increase in the rate-pressure product with a transient increase in the cardiac index but no alteration in the stroke index (Tweed et al. 1972, Idvall et al. 1979). After administration of racemic or $S(+)$ ketamine in equianalgesic doses, identical and significant increases in plasma cathecolamines, arterial blood pressure and heart rate are observed (Adams et al. 1992, Adams 1997). In our study similar results were observed, with arterial blood pressure and heart rate showing approximate values in both groups. Despite no occurrence of cardiac index alteration a significant reduction in the systolic index as well as an increase in systemic vascular resistance index was observed in both groups. A good equilibrium between the cardiostimulating effects of ketamine and the cardiodepressor effects of propofol is reached with the combine use of both drugs (Guit et al. 1991, Hui et al. 1995, Lerche et al. 2000).

In our study cardiac index and cardiac output showed stable values close to those of baseline and the peripheral vascular resistance was stable in all groups. A slight increase in the systolic arterial blood pressure was observed in all groups. The slight increase in the systolic arterial blood pressure at the time of ovarian pedicle clamping (M4) and the significant increase in heart rate in both groups at all time points, could be due to the stimulus of the sympathetic nervous system induced by ketamine and surgical procedure. In this study the new surgical stimulus was performed 3 minutes after the bolus injection of $20 \%$ of induction dose of propofol and the infusion rates were increased by $20 \%$ over the previous value. Previous studies have shown that the time required for plasmatic concentration equilibrium between blood and brain was 12 minutes (Stuart et al. 2000). In this view, we could have waited more than 12 minutes for the new surgical stimulus and recording of parameters.

In our study, the significant reduction of the systolic index at all time points, in the two studied groups (PRK: $50 \%$ in M2 and PSK: $-45 \%$ in M5), is probably due to the increase in heart rate and slight reduction of the cardiac index during anaesthesia, considering that this parameters are the result of the relationship between the cardiac index and the heart rate (Shoemaker 1995).

The intense respiratory depression observed after induction and at the beginning of drug infusion in both groups, is in agreement with other studies (Claeys et al. 1988, Morgan \& Legge 1989, Muir \& Gadawski 1998). In 
both groups, assisted ventilation was required for all animals. Spontaneous ventilation was restored within few minutes after infusion interruption. The same condition was observed by Schüttler et al. (1991) during anaesthesia with continuous infusion of propofol and ketamine in humans. Scarrone et al. (1990) observed a more pronounced respiratory depression in patients treated with propofol alone than in those treated with a combination of propofol and ketamine. Nevertheless, in the present study, the association of racemic ketamine and S-ketamine with propofol did not reduce the occurrence of its negative effects on the respiratory system, since ketamine is also a respiratory depressant. Hui et al. (1995) also observed respiratory depression with propofol/ racemic ketamine combination, in human patients.

In our study, during TIVA, arterial $\mathrm{pH}$ was lower than that reported in other studies in which propofol were used for maintenance (Claeys et al. 1988, Scarrone et al. 1990). This acidemia is probably due to the fact that our animals were initially maintained on spontaneous ventilation and only when the concentration values of expired carbon dioxide reached $45 \mathrm{mmHg}$, assisted ventilation was introduced.

The use of lower doses of S-ketamine in the PSK group may have influenced the faster recovery rate. Similar findings have been demonstrated in humans (White et al. 1985; Adams et al. 1992; Doenicke et al. 1992b; Calvey 1995) and in horses undergoing total intravenous anesthesia with $S(+)$ ketamine, romifidine and diazepam in comparison with racemic ketamine, romifidine and diazepam (Rossetti et al. 2008). During the recovery period, there was a reestablishment in the haemodynamic parameters due to lower concentrations of drugs in the central nervous system. Some studies in humans have shown that patients treated with equianaesthetic doses of $\mathrm{S}(+)$ ketamine felt less fear, disorientation and pain in postoperative period, and described more wellness and happiness when compared with racemic ketamine (White et al. 1980). These results may explain the faster recovery rate in the PSK group.

In the present study there was a need of more propofol supplementation in the PSK group. In this case, one can question the two to four fold increase in anaesthetic and analgesic potency of $S(+)$ Ketamine in relation to racemic ketamine (White et al. 1985, Mathisen et al. 1995, Lauretti et al. 2000). Moreover, it is also possible that the doses of propofol and/or both ketamines could be readjusted. Alternatively, the use of an opioid analgesic in premedication may reduce the required doses of propofol and ketamine for the overall anaesthetic effect as well as to reduce cardiovascular alterations.

\section{CONCLUSION}

The combination of propofol with $\mathrm{S}(+)$ ketamine and propofol with racemic ketamine for induction and maintenance of anaesthesia under TIVA has shown a good haemodynamic stability in both groups. However, an intense respiratory depression was also observed in which case assisted ventilation was made necessary. Although the effects of both associations were similar, the combination of propofol with $\mathrm{S}(+)$ ketamine showed better recovery, probably due to lower dose requirements. Further studies are necessary to evaluate different approaches in order to establish new protocols regarding the combine use of propofol and ketamine.

Acknowledgments.- The authors are grateful to Fundação de Amparo à Pesquisa do Estado de São Paulo (FAPESP) for supporting this experiment. The study was carried out at LIM-08, Faculdade de Medicina, Universidade de São Paulo.

\section{REFERENCES}

Adams H.A. 1997. S-(+)-ketamine. Circulatory interactions during total intravenous anesthesia and analgesia-sedation. Anaesthesist 46:10811087.

Adams H.A., Thiel A., Jung A., Fengler G. \& Hempelmann G. 1992. Studies using S-(+)-ketamine on probands: Endocrine and circulatory reactions, recovery and dream experiences. Anaethesist 41:588-596.

Badrinath S., Avramov M.N., Shadrick M., Witt T.R. \& Ivankovich A.D. 2000. The use of a ketamine-propofol combination during monitored anesthesia care. Anesth. Analg. 90:858-862.

Calvey T.N. 1995. Isomerism and anaesthetic drugs. Acta Anaesthesiol. Scand. 106(Suppl.):83-90.

Claeys M.A., Gepts E. \& Camu F.1988. Haemodynamic changes during anaesthesia induced and maintained with propofol. Brit. J. Anaesth. 60:3-9.

Doenicke A., Kugler J., Mayer. 1992b. Ketamine racemate or S(+) ketamine and midazolam. The effect on vigilance, efficacy and subjective findings. Anaesthesist 41:610-618.

Gauss A., Heinrich H. \& Wilder-Smith O.H.G. 1991. Echocardiographic assessment of the haemodynamic effects of propofol: a comparison with etomidate and thiopentone. Anaesthesia 46:99-105.

Goodchild C.S. \& Serrao J.M. 1989. Cardiovascular effects of propofol in the anaesthetized dog. Brit. J. Anaesth. 63:87-92.

Guit J.B.M., Koning H.M., Coster M.L., Niemeijer R.P.E. \& Mackie D.P. 1991. Ketamine as analgesic for total intravenous anaesthesia with propofol. Anaesthesia 46:24-27.

Hall L.W. \& Chambers J.P. 1987. A clinical trial of propofol infusion anaesthesia in dogs. J. Small Anim. Pract. 28:623-637.

Hara M., Kai Y. \& Ikemoto Y. 1993. Propofol activates GABA receptor chloride ionophore complex in dissociated hippocampal pyramidal neurons of the rat. Anesthesiology 79:781-788.

Hérnandez C., Parramón F., García-Velasco P., Vilaplana J., García Ch. \& Villalonga A. 1999. Estudio comparatico de tres técnicas de anestesia total intravenosa: midazolam-ketamina, propofol-ketamina y propofol-fentanilo. Rev. Esp. Anestesiol. Reanim. 46:154-158.

Hirota K. \& Lambert D.G. 1996. Ketamine: its mechanism(s) of action and unusual uses. Brit. J. Anaesth. 77:441-444.

Hui T.W., Short T.G., Hong W., Suen T., Gin T. \& Plummer J. 1995. Additive interactions between propofol and ketamine when used for anesthesia induction in female patients. Anesthesiology 82:641-648.

Idvall J., Ahlgren I., Aronsen K.F. \& Stenberg P. 1979. Ketamine infusions: pharmacokinetics and clinical effects. Brit. J. Anaesth. 51:1167-1173.

James I.F., Fischli W., Goldstein A. 1984. Opioid receptor selectivity of dynorphin gene products. J. Pharmacol. Exp. Ther., 228:8893-8899.

Lauretti G.R., Lima I.C.P.R., Buscatti R.Y. \& Reis M.P. 2000. Avaliação clínica dos efeitos hemodinâmicos, analgésicos, psicodélicos e do 
bloqueio neuromuscular da cetamina racêmica e de seu S(+) isômero. Revta Bras. Anestesiol. 50:357-362.

Lerche P., Nolan A.M. \& Reid J. 2000. Comparative study of propofol or propofol and ketamine for induction of anaesthesia in dogs. Vet. Rec. 146:571-574

Loh G. \& Dalen D. 2007. Low-dose ketamine in addition to propofol for procedural sedation and analgesia in the emergency department. Ann. Pharmacother. 41(3):485-492.

Maneglia R. \& Cousin M.T. 1988. A comparison between propofol and ketamine for anaesthesia in the elderly. Haemodynamic effects during induction and maintenance. Anaesthesia 43(Suppl.):109-111.

Mannarino R. 2002. Determinação da taxa de infusão mínima de propofol e propofol associado à lidicaína em cães (Canis familiaris). Dissertação de Mestrado, Faculdade de Medicina de Botucatu, Universidade Estadual Paulista, Botucatu. 128p.

Mathisen L.C., Skejelbred P. \& Skoglund L.A. 1995. Effect of ketamine, na NMDA receptor inhibitor, in acute and chronic orofacial pain. Pain 61:215-220.

Mayer M., Ochmann O., Doenicke A., Angster R. \& Suttmann H. 1990. Einflub einer propofol-ketamin-Narkose auf Kreislaufverhalten und Analgesie im Vergleich mit propofol-fentanyl. Anaesthesist 39:609616.

Mayer M.L. \& Miller R.J. 1990. Excitatory amino acid receptors: Second messengers and regulation of intracellular $\mathrm{Ca}^{+}$in mammalian neurones. Trends Pharmacol. Sci. 11:254-260.

Morgan D.W.T. \& Legge K. 1989. Clinical evaluation of propofol as an intravenous anaesthetic agent in cats and dogs. Vet. Rec. 14:31-33.

Muir W.W. \& Gadawski J.E. 1998. Respiratory and apnea induced by propofol in dogs. Am. J. Vet. Res., 59:57-161.

Nolan A. \& Reid J. 1993. Pharmacokinetics of propofol administered by infusion in dogs undergoing surgery. Brit. J. Anaesth. 70:546-551.

Parsons C.G., Magnago T.S.I. \& Headley P.M. 1998. At which "sigma" site are the spinal actions of ketamine mediated? Neurosc. Letters 85:322-328.

Pagel P.S. \& Warltier D.C. 1993. Negative inotropic effects of propofol as evaluated by the regional preload recruitable stroke work relationship in chronically instrumented dogs. Anesthesiology 78:100-108.

Palermo S., Cammardella M.P., Vallebona C., Cazzulo P., Frascá A., Francese G.P. \& Launo C. 1991. Valutazione clinica dell'anestesia com propofol-ketamina in chirurgia generale. Minerva Anestesiol. 57:91-96

Rossetti R.B., Gaido Cortopassi S.R., Intelizano T., Machado T.S.L. \&
Cruz R.S.F. 2008. Comparison of ketamine and S(+)-ketamine, with romifidine and diazepam, for total intravenous anesthesia in horses. Vet. Anaesth. Analg. 35(1):30-37.

Ryder S., Way W.L. \& Trevor A.J. 1978. Comparative pharmacology of the optical isomers of ketamine in mice. J. Pharmac. Exp. Ther. 212:198-202.

Scarrone S., Vivaldi N., D’Amico G., Ardizzone G. \& Spina G. 1990. Associazione propofol-ketamina nele anestesie di breve durata. Minerva Anestesiol. 56:809-811.

Schüttler J., Schüttler M., Kloos S., Nadstawek J. \& Schwilden H. 1991. Optimierte Dosierungsstrategien für die totale intravenöse Anaesthesie mit propofol und ketamin. Anaesthesist 40:199-204.

Shoemaker W.C. 1995. Diagnosis and treatment of the shock syndromes, p.85-102. In: Ayres S.M., Grenvik A., Holbrook P.R. \& Shoemaker W.C. (ed.), Textbook of Critical Care. 3rd ed. W.B. Saunders, Philadelphia.

Stoelting R.K.1999. Nonbarbiturate induction drugs, p.140-157. In: Stoelting R.K. (ed.), Pharmacology and Physiology in Anesthetic Practice. 3rd ed. Lippincott-Raven, Philadelphia.

Strümper D., Gogarten W., Duriex M.E., Hartleb K., Van Aken H., Marcus M.A. 2004. The effects of S+-ketamine and racemic ketamine on uterine blood flow in chronically instrumented pregnant sheep. Anesth. Analg. 98(2):497-502.

Stuart P.C., Scott S.M., Millar A., Kenny G.N.C. \& Russell D. 2000. Cp 50 of propofol with and without nitrous oxide $67 \%$. Brit. J. Anaesth. 84:638-639.

Terra P., Sudo G.Z., Sodo R.T. \& Moreira O.R. 1999. Análise comparativa da hipnose e da analgesia entre os estereisômeros da cetamina. Revta Bras. Anestesiol. 49(Suppl.24):CBA170.

Turner D.M., Ilkin J.E., Rose R.J. \& Warren J.M. 1974. Respiratory and cardiovascular effects of five drugs used as sedatives in the dog. Aust. Vet. J. 50:260-265

Tweed W.A., Minuck M. \& Mymin D. 1972. Circulatory responses to ketamine anesthesia. Anesthesiology 37:613-619.

Watkins S.B., Hall L.W. \& Clarke K.W. 1987. Propofol as an intravenous anesthetic agent in dogs. Vet. Rec. 120:326-329.

White P.F., Ham J. \& Way W.L. 1980. Pharmacology of ketamine isomers in surgical patients. Anesthesiology 52:231-239.

White P.F., Shüttler J. \& Shafer A. 1985. Comparative pharmacology of the ketamine isomers. Brit. J. Anaesth. 57:197-203.

White P.F., Way W.L. \& Trevor A.J. 1982. Ketamine: Its pharmacology and therapeutic uses. Anesthesiology 56:119-136. 